\title{
Screening of the Anticonvulsant Activity of Some Isatin Derivatives in Experimental Seizure Models and Its Effect on Brain GABA Levels in Mice
}

\author{
Venkateshwarlu Eggadi ${ }^{1,2}$, Umasankar Kulandaivelu ${ }^{2}$, Sharvanabhava B S ${ }^{2}$, Venkateshwar Rao Jupally ${ }^{3, *}$ \\ ${ }^{1}$ Department of Biotechnology, AcharyaNagarjuna University, Guntur, India \\ ${ }^{2}$ Vaagdevi College of Pharmacy, Hanamkonda, Warangal, India \\ ${ }^{3}$ TallaPadmavathi College of Pharmacy, Orus, Warangal, India \\ *Corresponding author: eggadivenkey@gmail.com
}

Received December 28, 2012; Revised Arpil 27, 2013; Accepted Arpil 29, 2013

\begin{abstract}
The modern therapeutic approaches of antiepileptic agents against epileptic patients are showing many side effects, dose related effects and chronic toxicity. The aim of our present work is to evaluate anticonvulsant activity of isatin derivatives (Ia-Ij) to reduce the side-effects and increase the percentage protection from various stages of convulsions. No animals showed toxic effects even up to $2000 \mathrm{mg} / \mathrm{kg}$. It is evident that $\mathbf{I b}, \mathbf{I e}, \mathbf{I h}, \mathbf{I i}$ and $\mathbf{I j}$ showed anticonvulsant effect at the dose levels of 10 and $100 \mathrm{mg} / \mathrm{kg}$ in MES test and except Ij all other derivatives exhibited antiepileptic effect at 10 and $100 \mathrm{mg} / \mathrm{kg}$ in PTZ induced convulsions test. The isatin derivatives (Ib, Ie, Ih and Ii) which proved antiepileptic effect in both MES and PTZ induced convulsion models are selected and GABA levels in brain were estimated. They showed significant increase of GABA levels in brain.
\end{abstract}

Keywords: isatin, anticonvulsant activity, pentylene tetrazole, maximum electric shock, GABA

\section{Introduction}

Epilepsy is the most common neurological disorder and affects around 50 million people worldwide [1] and it is characterized by recurrent unprovoked seizures. Seizures are induced mainly due to imbalance between inhibitory and excitatory neurotransmitters [2]. They are characterized by uncontrolled involuntary shaking which may be partial seizures involving only one part of the body or generalized seizures involving entire body and may accompanied by loss of consciousness. There are twice as many people living with epilepsy in low and lower-middle income countries than higher income nations and more than 60 per cent of those affected in these regions are not accessed with any appropriate treatment [3]. The incidence rate of epilepsy in the developed and developing countries approximately ranges from 25-50 and 30-115 per one lakh people per year respectively [4]. The prevalence of epilepsy in the developed countries ranges from 4-10 and 14-57 per thousand people in developing countries per year respectively [5]. Antiepileptic drugs are effective in controlling seizures in about $70-80 \%$ of patients, but their use is often limited by side effects. In addition, these are used to treat or prevent convulsions induced by other brain diseases like trauma, brain infections, brain tumours and cerebral infarction [2]. The treatment of seizures is always a challenge for clinical practitioners and researchers to avoid the therapeutic failure in $20-25 \%$ of patients. This stimulated an intensive research to develop novel antiepileptic drugs.
Isatin has an indole moiety which exhibits variety of biological activities like anticonvulsant [6], anxiolytic [7], anticancer [8], anti-inflammatory, analgesic, antipyretic [9], antifungal [10], antiviral [11], anti-angiogenic [12] and anti-parkinsonian effects [13] etc.

From the above observations, the present work was carried out to synthesize some new isatin-3-[N ${ }^{2}-(2-$ benzalaminothiazol-4-yl)] hydrazones and these are screened for anticonvulsant activity.

\section{Materials and Methods}

\section{Chemicals}

Diazepam (Ranbaxy Laboratories, India), Phenytoin (Sun Pharmaceuticals India. Ltd, India). Pentylyne tetrazole, (PTZ) (Sigma-Aldrich, India). Isatin derivatives (the structure and physical properties of Ia-Ij are addressed in Table 1).

Animals

Swiss albino mice (20-25gm) were selected and procured from Mahaveer enterprises, Hyderabad, India. They were acclimatized for one week under standard laboratory conditions $\left(25 \pm 2^{\circ} \mathrm{C}\right.$, relative humidity of 45 to $55 \%$ and 12:12 hr light and dark cycle) and fed with standard rodent pellet diet and water ad libitum. Each group contains six animals and are used for the mentioned research activities. The study protocol was approved by Institutional Animal Ethics Committee (IAEC NO: 1047/ac/07/CPCSEA).

\subsection{Acute Toxicity Studies}


Healthy adult female Swiss albino mice were fasted overnight and test compounds in $0.1 \%$ sodium carboxy methyl cellulose (CMC) were administered i.p, in doses up to $2000 \mathrm{mg} / \mathrm{kg}$. The control group received only vehicle
(0.1\% CMC).The animals were observed for one month from the time of administration of test compounds and mortality was recorded [14].

Table 1. Effect of isatin-3-[N2-(2-benzalaminothiazol-4-yl)] hydrazones on PTZ induced convulsions

\begin{tabular}{|c|c|c|c|c|c|c|c|c|c|}
\hline \multirow[b]{2}{*}{ Treatment } & \multirow[b]{2}{*}{$\mathrm{R}$} & \multirow[b]{2}{*}{$\mathrm{R}^{1}$} & \multirow{2}{*}{$\begin{array}{l}\text { Dose } \\
(\mathrm{mg} / \mathrm{kg})\end{array}$} & \multirow{2}{*}{$\begin{array}{l}\text { Latency } \\
\text { (sec/0.5hr) }\end{array}$} & \multirow{2}{*}{$\begin{array}{l}\text { Onset of tonic } \\
\text { convulsion } \\
\text { (sec/ } 0.5 \mathrm{hr})\end{array}$} & \multicolumn{2}{|c|}{$\begin{array}{l}\text { Status of animal } \\
\text { after } 0.5 \mathrm{hr}\end{array}$} & \multicolumn{2}{|c|}{$\begin{array}{l}\text { Status of animal } \\
\text { after } 24 \mathrm{hrs}\end{array}$} \\
\hline & & & & & & $\begin{array}{l}\text { No of } \\
\text { alive } \\
\text { animals }\end{array}$ & $\%$ protection & $\begin{array}{l}\text { No of } \\
\text { alive } \\
\text { animals }\end{array}$ & $\%$ protection \\
\hline Control & --- & --- & ---- & $48.26 \pm 5.62$ & $412.32 \pm 4.84$ & $0 / 6$ & 0.00 & $0 / 6$ & 0.00 \\
\hline Diazepam & --- & --- & 5 & No clonus & No tonic & $6 / 6$ & 100.00 & $6 / 6$ & 100.00 \\
\hline \multirow{2}{*}{ Ia } & \multirow{2}{*}{$\mathrm{H}$} & \multirow{2}{*}{$\mathrm{H}$} & 10 & $\begin{array}{c}56.80 \pm \\
2.36^{*}\end{array}$ & $418.44 \pm 2.75^{*}$ & $1 / 6$ & 16.67 & $1 / 6$ & 16.67 \\
\hline & & & 100 & $\begin{array}{l}175.68 \pm \\
3.28 * * *\end{array}$ & $789.66 \pm 1.46^{* * *}$ & $2 / 6$ & 33.33 & $2 / 6$ & 33.33 \\
\hline \multirow{2}{*}{ Ib } & \multirow{2}{*}{$\mathrm{H}$} & \multirow{2}{*}{$4-\mathrm{Cl}$} & 10 & $\begin{array}{l}56.04 \pm \\
4.65^{*} \\
\end{array}$ & $418.52 \pm 2.65^{*}$ & $2 / 6$ & 33.33 & $2 / 6$ & 33.33 \\
\hline & & & 100 & $\begin{array}{l}200.56 \pm \\
5.42 * * *\end{array}$ & $915.43 \pm 3.52^{* * * *}$ & $4 / 6$ & 66.66 & $4 / 6$ & 66.66 \\
\hline \multirow{2}{*}{ Ic } & \multirow{2}{*}{$\mathrm{H}$} & \multirow{2}{*}{$\begin{array}{c}4- \\
\mathrm{N}\left(\mathrm{CH}_{3}\right)_{2}\end{array}$} & 10 & $\begin{array}{c}58.14 \pm \\
1.98^{*} \\
\end{array}$ & $417.23 \pm 3.65^{*}$ & $1 / 6$ & 16.67 & $1 / 6$ & 16.67 \\
\hline & & & 100 & $\begin{array}{c}175.54 \\
\pm 2.68 * * *\end{array}$ & $800.45 \pm 2.98$ **** & $3 / 6$ & 50.00 & $3 / 6$ & 50.00 \\
\hline \multirow{2}{*}{ Id } & \multirow{2}{*}{$\mathrm{H}$} & \multirow{2}{*}{$\begin{array}{c}\text { 4-OH, } \\
3-\mathrm{OCH}_{3}\end{array}$} & 10 & $\begin{array}{c}56.90 \pm \\
6.34^{*}\end{array}$ & $418.84 \pm 2.79^{*}$ & $1 / 6$ & 16.67 & $1 / 6$ & 16.67 \\
\hline & & & 100 & $\begin{array}{l}175.84 \pm \\
5.83 * * *\end{array}$ & $810.66 \pm 1.86^{* * *}$ & $2 / 6$ & 33.33 & $2 / 6$ & 33.33 \\
\hline \multirow{2}{*}{ Ie } & \multirow{2}{*}{$\begin{array}{c}5- \\
\mathrm{CH}_{3}\end{array}$} & \multirow{2}{*}{$4-\mathrm{Cl}$} & 10 & $\begin{array}{c}54.34 \pm \\
4.56^{*}\end{array}$ & $418.74 \pm 1.94 *$ & $2 / 6$ & 33.33 & $2 / 6$ & 33.33 \\
\hline & & & 100 & $\begin{array}{l}210.34 \pm \\
1.98 * * *\end{array}$ & $923.48 \pm 2.93^{* * *}$ & $3 / 6$ & 50.00 & $3 / 6$ & 50.00 \\
\hline \multirow{2}{*}{ If } & \multirow{2}{*}{$\begin{array}{c}5- \\
\mathrm{CH}_{3}\end{array}$} & \multirow{2}{*}{$\begin{array}{c}\text { 4-OH, } \\
3-\mathrm{OCH}_{3}\end{array}$} & 10 & $\begin{array}{c}56.79 \pm \\
6.14^{*}\end{array}$ & $417.62 \pm 3.56^{*}$ & $1 / 6$ & 16.67 & $1 / 6$ & 16.67 \\
\hline & & & 100 & $\begin{array}{l}185.84 \pm \\
5.33 * * *\end{array}$ & $795.34 \pm 2.57 * * *$ & $3 / 6$ & 50.00 & $3 / 6$ & 50.00 \\
\hline \multirow{2}{*}{ Ig } & \multirow{2}{*}{$\begin{array}{c}5- \\
\mathrm{CH}_{3}\end{array}$} & \multirow{2}{*}{$\mathrm{H}$} & 10 & $\begin{array}{c}56.39 \pm \\
6.84 *\end{array}$ & $418.02 \pm 2.86^{*}$ & $1 / 6$ & 16.67 & $1 / 6$ & 16.67 \\
\hline & & & 100 & $\begin{array}{l}193.84 \pm \\
5.63 * * *\end{array}$ & $850.43 \pm 1.99 * * *$ & $3 / 6$ & 50.00 & $3 / 6$ & 50.00 \\
\hline \multirow{2}{*}{ Ih } & \multirow{2}{*}{$5-\mathrm{Cl}$} & \multirow{2}{*}{$\begin{array}{c}\text { 4-OH, } \\
3-\mathrm{OCH}_{3}\end{array}$} & 10 & $\begin{array}{c}55.34 \pm \\
2.64^{*}\end{array}$ & $418.35 \pm 3.68^{*}$ & $3 / 6$ & 50.00 & $3 / 6$ & 50.00 \\
\hline & & & 100 & $\begin{array}{l}230.28 \pm \\
3.85 * * *\end{array}$ & $930.45 \pm 2.56^{* * *}$ & $5 / 6$ & 83.33 & $5 / 6$ & 83.33 \\
\hline & & & 10 & $\begin{array}{c}54.02 \pm \\
2.46^{*}\end{array}$ & $417.77 \pm 5.84^{*}$ & $03 / 6$ & 50.00 & $03 / 6$ & 50.00 \\
\hline Ii & $5-\mathrm{Cl}$ & $4-\mathrm{Cl}$ & 100 & $\begin{array}{l}286.12 \pm \\
4.28 * * *\end{array}$ & $945.65 \pm 3.62 * * *$ & $05 / 6$ & 83.33 & $05 / 6$ & 83.33 \\
\hline & & & 10 & $49.23 \pm 2.56$ & $414.34 \pm 2.45$ & $0 / 6$ & 0.00 & $0 / 6$ & 0.00 \\
\hline $\mathbf{I j}$ & $\begin{array}{c}5- \\
\mathrm{NO}_{2}\end{array}$ & $\begin{array}{l}\text { 4-OH, } \\
3-\mathrm{OCH}_{3}\end{array}$ & 100 & $\begin{array}{c}100.34 \pm \\
2.63\end{array}$ & $518.56 \pm 2.26$ & $0 / 6$ & 0.00 & $0 / 6$ & 0.00 \\
\hline
\end{tabular}

$\%$ protection $=$ no of animals alive/no of animals used $\mathrm{x} 100$; Values are Mean $\pm \mathrm{SD}, \mathrm{n}=6$ in each group. $* \mathrm{P}<0.05, * * \mathrm{P}<0.01, * * * \mathrm{P}<0.001$ when compared with control group (Newman-Keuls multiple comparison test)

\subsection{Anticonvulsant Activity Against PTZ Induced Seizures}

Animals were assigned into three groups viz., control, standard and test groups. The control group received $0.1 \%$ CMC i.p, standard group animals were given diazepam $5 \mathrm{mg} / \mathrm{kg}$ i.p and test groups were injected with isatin derivatives ( Ia-Ij) at dose levels of 10 and 100mg/kg i.p. One hour after the administration of these substances to the respective groups, all the animals of assigned groups were administered with PTZ (80mg/kg; s.c) [15]. Each animal was observed up to $0.5 \mathrm{hr}$ for onset of clonus, tonic convulsions and status of animals were also recorded. After $24 \mathrm{hrs}$ the percentage protection of animals was calculated [16].

\subsection{Anticonvulsant Activity Against MES Induced Seizures}

Animals were checked for sensitivity to electric shock $24 \mathrm{hr}$ prior to administration of test compounds and those animals which fail to show hind limb tonic extension were rejected. Animals were assigned into three groups viz., 
control, standard and test groups. The control group received $0.1 \%$ CMC i.p, standard group animals were given phenytoin $25 \mathrm{mg} / \mathrm{kg}$ i.p [17] and test groups were injected with isatin derivatives (Ia-Ij) at dose levels of 10 and $100 \mathrm{mg} / \mathrm{kg}$ i.p. A $60 \mathrm{~Hz}$ alternating current of $150 \mathrm{~mA}$ intensity for $0.2 \mathrm{sec}$ using corneal electrodes elicited maximal seizures. A drop of lignocaine was applied to the corneal electrodes which ensure better contact to the animal $[18,19]$. This current intensity elicited complete tonic extension of the hind limbs in control group. A clear rectangular polypropylene cage with an open top which permits full view of the animal to observe various phases of convulsions like tonic, flexion, extension, stupor and mortality due to convulsions was used.

\subsection{Estimation of Brain GABA Content}

Following the methods of Lowe et al., the GABA contents in the brains were estimated. Animals were scarified by decapitation, the brains were exposed and separated the forebrain region. It was blotted, weighed and placed in a beaker containing $5 \mathrm{ml}$ of ice cold TCA $(10 \% \mathrm{w} / \mathrm{v})$ and homogenised. The homogenated brain was centrifuged at $10,000 \mathrm{rpm}$ for $10 \mathrm{~min}$ at $0^{\circ} \mathrm{C}$. Then $0.1 \mathrm{ml}$ of supernatant was dissolved in $0.2 \mathrm{ml}$ of ninhydrin solution $(0.15 \mathrm{M})$ in a $0.5 \mathrm{M}$ of carbonate-bicarbonate buffer $(0.5, \mathrm{pH}$ 9.95). This mixture is kept in a water bath for $30 \mathrm{~min}$ maintaining $60^{\circ} \mathrm{C}$ and then cooled. The cooled mixture is treated with $5 \mathrm{ml}$ of copper tartarate reagent and kept aside for 10min. Fluorescence was observed at $377 / 455 \mathrm{~nm}$ by using spectrofluorimeter [20].

\section{Statistical analysis}

Results were expressed as Mean \pm SD. Statistical significance was calculated by applying one way ANOVA. $\mathrm{P}<0.05$ was considered as significant (Newman-Keuls multiple comparison test).

\section{Results}

\subsection{Acute Toxicity Studies}

The compounds used in our work were found to be safe and no toxic effects were seen even at higher doses of $2000 \mathrm{mg} / \mathrm{kg}$. Some behavioural changes were recorded but no toxic symptoms.

\subsection{Anticonvulsant Activity}

All the isatin derivatives (Ia-Ij) were evaluated for their anticonvulsant effect by performing MES and PTZ activities are most widely accepted models and the compounds are screened at two dose levels 10 and $100 \mathrm{mg} / \mathrm{kg}$. The output was given in Table 1 and Table 2 . In MES model, the compounds Ib, Ie, Ih, Ii and Ij showed significant reduction in various phases of epileptic seizures when compared with control. In PTZ test, the compounds Ia, Ib, Ic, Id, Ie, If, Ig, Ih and Ii exhibited a significant anticonvulsant activity by increasing both latency time (onset of clonus) and onset of tonic convulsions. All the compounds exhibited anticonvulsant activity in dose dependent manner.

Table 2. Effect of isatin-3-[N2-(2-benzalaminothiazol-4-yl)] hydrazones on MES induced convulsions

\begin{tabular}{|c|c|c|c|c|c|c|}
\hline \multirow{2}{*}{ Treatment } & \multirow{2}{*}{$\begin{array}{c}\text { Dose } \\
(\mathrm{mg} / \mathrm{kg})\end{array}$} & \multicolumn{4}{|c|}{ Various phases of convulsions (time in sec) } & \multirow{2}{*}{$\%$ Protection } \\
\hline & & Flexion & Extensor & Colonus & Stuper & \\
\hline Control & $\begin{array}{c}0.1 \% \mathrm{Na} \\
\mathrm{CMC}\end{array}$ & $8.30 \pm 0.35$ & $15.24 \pm 0.40$ & $15.32 \pm 0.32$ & $9.25 \pm 0.30$ & NP \\
\hline Phenytoin & 25 & $3.25 \pm 0.15 * * *$ & $00 \pm 00 * * *$ & $8.32 \pm 0.34 * * *$ & $3.56 \pm 0.15^{* * *}$ & 100 \\
\hline \multirow{2}{*}{ Ia } & 10 & NA & NA & NA & NA & NP \\
\hline & 100 & NA & NA & NA & NA & NP \\
\hline \multirow{2}{*}{ Ib } & 10 & $7.87 \pm 0.45^{*}$ & $14.33 \pm 0.54 *$ & $14.75 \pm 0.22 *$ & $8.38 \pm 0.42 *$ & 33.33 \\
\hline & 100 & $6.22 \pm 0.41 * * *$ & $10,44 \pm 0.32 * * *$ & $9.95 \pm 0.43 * * *$ & $6.71 \pm 0.47 * * * *$ & 50.00 \\
\hline \multirow{2}{*}{ Ic } & 10 & NA & NA & NA & NA & NP \\
\hline & 100 & NA & NA & NA & NA & NP \\
\hline \multirow{2}{*}{ Id } & 10 & NA & NA & NA & NA & NP \\
\hline & 100 & NA & NA & NA & NA & NP \\
\hline \multirow{2}{*}{ Ie } & 10 & $7.67 \pm 0.35 *$ & $14.47 \pm 0.56^{*}$ & $14.82 \pm 0.32 *$ & $8.49 \pm 0.52 *$ & 33.33 \\
\hline & 100 & $5.62 \pm 0.21 * * *$ & $6.62 \pm 0.36 * * *$ & $9.73 \pm 0.33 * * *$ & $6.64 \pm 0.77 * * *$ & 50.00 \\
\hline \multirow{2}{*}{ If } & 10 & NA & NA & NA & NA & NP \\
\hline & 100 & NA & NA & NA & NA & NP \\
\hline \multirow{2}{*}{ Ig } & 10 & NA & NA & NA & NA & NP \\
\hline & 100 & NA & NA & NA & NA & NP \\
\hline \multirow{2}{*}{ Ih } & 10 & $7.69 \pm 0.38 *$ & $14.36 \pm 0.52 *$ & $14.73 \pm 0.12 *$ & $8.43 \pm 0.62 *$ & 50.00 \\
\hline & 100 & $5.22 \pm 0.25 * * *$ & $6.12 \pm 0.32 * * *$ & $9.46 \pm 0.23 * * *$ & $6.26 \pm 0.67 * * *$ & 83.33 \\
\hline \multirow{2}{*}{ Ii } & 10 & $7.73 \pm 0.16^{*}$ & $14.34 \pm 0.93^{*}$ & $14.67 \pm 0.21 *$ & $8.48 \pm 0.12 *$ & 50.00 \\
\hline & 100 & $4.32 \pm 0.24 * * *$ & $5.12 \pm 0.26 * * *$ & $9.12 \pm 0.56^{* * * *}$ & $5.65 \pm 0.31 * * *$ & 83.33 \\
\hline \multirow{2}{*}{$\mathbf{I j}$} & 10 & $7.68 \pm 0.43 *$ & $14.72 \pm 0.33 *$ & $14.91 \pm 0.25^{*}$ & $8.79 \pm 0.22 *$ & 33.33 \\
\hline & 100 & $7.59 \pm 0.22 *$ & $14.63 \pm 0.32 *$ & $14.86 \pm 0.23^{*}$ & $8.63 \pm 0.41 *$ & 50.00 \\
\hline
\end{tabular}

$\mathbf{N A}=$ No activity; $\mathbf{N P}=$ No protection at $10,100 \mathrm{mg} / \mathrm{kg}$ dose; Values are Mean $\pm \mathrm{SD}, \mathrm{n}=6$ in each group. $* \mathrm{P}<0.05, * * \mathrm{P}<0.01, * * * \mathrm{P}<0.001$ when compared with control group (Newman-Keuls multiple comparison test)

\subsection{Estimation of Brain GABA Content}

For estimation of GABA levels in brain of screened animals, test compounds Ib, Ie, Ih and Ii were selected which showed significant anticonvulsant activity in both models. In MES and PTZ models, GABA levels were significantly $(p<0.001)$ decreased in forebrain of epileptic control animals. The compounds Ib, Ie, Ih and Ii at the doses of 10 and $100 \mathrm{mg} / \mathrm{kg}$, standard drugs 
Phenytoin and diazepam treated animals showed a significant $(p<0.05 \& p<0.001)$ increase in GABA levels in forebrain of animals. The results of estimation of GABA content in brain are tabulated in Table 3.

Table 3. Effect of isatin derivatives on GABA levels in rat brain after MES and PTZ induced convulsion

\begin{tabular}{|c|c|c|c|}
\hline \multirow{2}{*}{ Treatment } & \multirow{2}{*}{$\begin{array}{c}\text { Dose } \\
\text { (mg/kg } \\
\text { body } \\
\text { wt) }\end{array}$} & \multicolumn{2}{|c|}{ GABA Levels } \\
\hline & & MES & PTZ \\
\hline Control & --- & $278.34 \pm 1.34$ & $288.32 \pm 1.81$ \\
\hline $\begin{array}{l}\text { Disease } \\
\text { control }\end{array}$ & --- & $230.12 \pm 2.12 * * *$ & $200.14 \pm 1.26 * * *$ \\
\hline Phenytoin & 25 & $273.32 \pm 1.15^{* * * *}$ & --- \\
\hline Diazepam & 5 & --- & $285.22 \pm 1.54 * * *$ \\
\hline \multirow{2}{*}{ Ib } & 10 & $232.50 \pm 2.23 *$ & $202.23 \pm 1.92 *$ \\
\hline & 100 & $266.43 \pm 1.62 * * *$ & $258.21 \pm 1.32 * * *$ \\
\hline \multirow{2}{*}{ Ie } & 10 & $233.00 \pm 2.53 *$ & $202.53 \pm 1.24 *$ \\
\hline & 100 & $269.41 \pm 1.92 * * *$ & $265.11 \pm 1.13 * * *$ \\
\hline \multirow{2}{*}{ Ih } & 10 & $234.20 \pm 2.13^{* *}$ & $203.12 \pm 1.51^{* *}$ \\
\hline & 100 & $272.63 \pm 1.32 * * *$ & $275.18 \pm 1.72 * * *$ \\
\hline \multirow{2}{*}{ Ii } & 10 & $234.50 \pm 2.33 * *$ & $203.53 \pm 1.45^{* *}$ \\
\hline & 100 & $272.42 \pm 1.12 * * *$ & $279.28 \pm 1.42 * * *$ \\
\hline
\end{tabular}

Values are Mean $\pm \mathrm{SD}, \mathrm{n}=6$ in each group. $* \mathrm{P}<0.05, * * \mathrm{P}<0.01$,

$* * * \mathrm{P}<0.001$ when compared with disease control group (Newman-Keuls multiple comparison test).Units $=\mathrm{pg} / \mathrm{mg}$ of wet tissue

\section{Discussion}

In the present investigation, it is evident that isatin derivatives were able to reduce the epileptic seizures induced by MES and PTZ in the laboratory animals. From the literature, GABAergic transmission is closely associated with the induction of epilepsy in animals [21]. In central nervous system, GABA is the major inhibitory neurotransmitter (NT) and slight deficiency in this transmitter may lead to hyper excitability and pathological neuronal discharge leading to epilepsy. In most of the antiepileptic drugs an enhancement of GABAergic inhibitory transmission is responsible which directly bind, activate $\mathrm{GABA}_{\mathrm{A}}$ receptors or influence GABA release, transport and metabolize. GABA mediated chlorine channel opening is closely associated with induction and onset of seizures [22]. PTZ is non-competitive antagonist which blocks GABA mediated $\mathrm{Cl}$ influx and leads to enhanced release of excitatory neurons to release NTs such as $\alpha$-amino-3-hydroxy-5-methyl-4-isoxazolepropionic acid receptor (AMPA) and N-methyl-D-aspartic acid (NMDA).This results in neuronal excitotoxicity leading to seizures and convulsions characterized by clonic and tonic phases. The substitutions of different substituent's $(\mathrm{H}$, $\mathrm{CH}_{3}, \mathrm{NO}_{2}$ and $\mathrm{Cl}$ ) at $5^{\text {th }}$ position in the isatin ring significantly shows the anticonvulsant activity [23]. Verma et al., identified 5-Br isatin as anticonvulsant agent, here we replaced $\mathrm{Br}$ with $\mathrm{Cl}$ because of its bioisosterism [24]. In our investigation, the compounds having mild deactivator like chloride at the $5^{\text {th }}$ position of isatin ring (Ih and Ii) shows a good anticonvulsant activity against
MES and PTZ test without any toxicity. Substitution of strong deactivator like nitro group at $5^{\text {th }}$ position of isatin ring, showed blockade of PTZ induced convulsions [25] but in the present investigation the nitro derivative (Ij) exhibited less potency due to other peripheral part of molecule. In this series, the isatin ring substituted with electron donating and mild deactivating substituents shown potency but the strong deactivating group exhibited less potency.

The 5-methyl substituent's with the least negative inductive effect on the isatin ring was found to yield more active compounds [23], Ie, If and Ig also exhibited anticonvulsant activity due to the introduction of hydrophobic group i.e., increased lipophilic nature. Among all the compounds, Ie showed anticonvulsant activity in MES model because of the presence of methyl group on isatin and chlorine substitution in the phenyl ring at $4^{\text {th }}$ position where as the unsubstituted (Ig) and substituted with strong electron donating group like $\mathrm{OH}$ and $\mathrm{OCH}_{3}$ on phenyl ring (If) showed against to PTZ model. Unsubstituted isatin derivatives (Ia-Id) showed anticonvulsant activity but the phenyl ring of side chain has strong electron donating group $\left(\mathrm{N}\left(\mathrm{CH}_{3}\right)_{2}, \mathrm{OH}\right)$ is less potent when compared with phenyl ring substituted with weak electron donating group $\left(\mathrm{Cl}\right.$; Ib) at $4^{\text {th }}$ position against both models but remaining three compounds were active against only PTZ model and Pandeya et al also observed same kind of effect [25].

In present study, the established antiepileptic drugs such as phenytoin and diazepam restored the GABA levels in brain. Similarly in our investigation isatin derivatives (Ib, Ie, Ih and Ii) significantly ( $\mathrm{p}<0.05, \mathrm{p}<0.01$ and $\mathrm{p}<$ 0.001 ) increased GABA levels in forebrain of animals.

\section{Conclusion}

In our investigation GABA is involved in both MES and PTZ induced convulsion models. Our findings support the hypothesis that decrease in GABA levels of mice brain after induction of convulsions. The animals treated with isatin derivatives (Ib, Ie, Ih and Ii) significantly restore the GABA levels in brain. We conclude that our isatin derivatives possess antiepileptic activity by restoring the GABA levels in mice brain.

\section{Acknowledgements}

The authors are grateful to Secretary, Viswambhara Educational Society, Warangal for providing the necessary facilities to carry out the study.

\section{References}

[1] Sander, J.W, The epidemiology of epilepsy revisited. Curr Opin Neurol, 2003, 165-170.

[2] Rang, H.P, Dale, M.M, Ritter, J.M. and Moore,P.K, Textbook of Pharmacology. Churchill Livingstone,UK, 2007,575-584.

[3] Newton, C.R. and Garcia, H.H, Epilepsy in poor regions of the world. Lancet,2012, 1193-1201.

[4] Kotsopoulos, I.A.W., Van Merode, T., Kessels, F.G.H.,De Krom, M.C.T.F., and Knottnerus, J.A, "Systematic Review and Meta analysis of Incidence Studies of Epilepsy and Unprovoked Seizures", Epilepsia, 43(11).1402-1409.Nov.2002. 
[5] Bell, G.S. and Sander, J .W, CPD-Education and self-assessment the epidemiology of epilepsy: the size of the problem. Seizure, 10(4).306-316. June. 2001.

[6] Kaur, H., Kumar, S. and Kumar, A, Synthesis, Antipsychotic and Anticonvulsant Activity of some new pyrazolinyl/isoxazolinylindol-2ones. Int J ChemTech Res, 2(2).1010-1019. April-June.2010.

[7] Geronikaki, A., Babaev, E., Dearden, J., et al. "Design, synthesis, computational and biological evaluation of new anxiolytics”,Bioorg Med Chem, 12(24). 6559-6568. Sept.2004.

[8] Gudipati, R. Anreddy, R.N.R. and Manda, S. "Synthesis, characterization and anticancer activity of certain 3-\{4-(5mercapto-1, 3, 4-oxadiazole-2-yl) phenylimino $\}$ indolin-2-one derivatives", Saudi Pharm, 19(3).153-158.July.2011.

[9] Venkateshwaralu, E., Venkateshwar Rao, J., Umasankar, K. and Dheeraj, G. "Sudy of anti-inflammatory, analgesic and antipyretic activity of novel isatin derivatives". Asian J Pharm Clin Res, 5(4).187-190. August.2012.

[10] Rodríguez-Argüelles, M.C., Mosquera-Vázquez, S., TourónTouceda, P., Sanmartín-Matalobos, J., García-Deibe, A.M., Belicchi-Ferrari, M., Pelosi, G., Pelizzi, C. and Zani F. "Complexes of 2-thiophenecarbonyl and isonicotinoyl hydrazones of 3-(N-methyl) isatin:A study of their antimicrobial activity". $J$ Inorg Biochem, 101(1).138-147.Jan. 2007.

[11] Jiang, T., Kuhen, K.L., Wolff, K., Yin, H., Bieza, K., Caldwell, J., Bursulaya, B., Tuntland, T., Zhang, K., Karanewsky, D. and He Y "Design, synthesis, and biological evaluations of novel oxindoles as HIV-1 non-nucleoside reverse transcriptase inhibitors". Bioorg Med Chem Lett, 16(8).2109-2112.Apr.2006.

[12] Maskell, L., Blanche, E.A., Colucci, M.A., Whatmore, J.L. and Moody, C.J. "Synthesis and evaluation of prodrugs for antiangiogenic pyrrolylmethylidenyl oxindoles". Bioorg Med Chem Lett, 17(6).1575-1578. March. 2007.

[13] Igosheva, N., Lorz, C., O'Conner, E., Glover, V. and Mehmet, H. "Isatin, an endogenous monoamine oxidase inhibitor, triggers a dose- and time-dependent switch from apoptosis to necrosis in human neuroblastoma cells". Neurochem. Int, 47(3).216-224. Aug.2005.
[14] Van den Heuvel, M.J., Clark, D.G., Fielder, R.J., Koundakjian, P.P., Oliver, G.J.A., Pelling, D., Tomlinson, N.J. and Walker, A.P, "The international validation of a fixed-dose procedure as an alternative to the classical LD50 test". Food Chem Toxicol, 28(7).469-482. Jul.1990.

[15] Turner, R.A, Anticonvulsants. Screening methods in Pharmacology, Academic Press New York, 1965, 64-65.

[16] Khosla,P. and Pandhi.P, "Anticonvulsant effect of nimodipine alone and in combination with diazepam on PTZ induced status epilepticus". Indian J Pharmacol, 33.208-211. Sept.2001.

[17] Swinyard, E.A., Brown, W.C. and Goodman, L.S. "Comparative assays of antiepileptic drugs in mice and rats". J Pharmacol Exp Ther, 106(3).319-330. Nov.1952.

[18] Löscher, W. and Schmidt, D. "Which animal models should be used in the search for new antiepileptic drugs? A proposal based on experimental and clinical considerations". Epilepsy Res, 2(3):145-181.May-June.1988.

[19] Swinyard, E.A. Electrically induced convulsions. Raven Press, New York,433-458. M.1972.

[20] Lowe, I.P., Robins, E. and Eyerman, G.S. "The fluorometric measurement of glutamic decarboxylase and its distribution in brain". J Neurochem, 3(1).8-18.Oct.1958.

[21] Katzung, B.G. Basic and Clinical Pharmacology. McGraw Hill, New York, 2009. 357-369.

[22] Tripathi, K.D. Essentials of Medical pharmacology,Jaypee Brothers Medical Publishers Ltd, New Delhi, 2008,394-395.

[23] Sridhar, S.K., Pandeya, S.N., Stables, J.P. and Ramesh, A. "Anticonvulsant activity of hydrazones, Schiff and Mannich bases of isatin derivatives". Eur J Pharm Sci, 16(3).129-132. Aug.2002.

[24] Verma, M., Pandeya, S.N., Singh, K.N.and Stables, J.P. "Anticonvulsant activity of Schiff bases of isatin derivatives". Acta Pharm, 54.49-56. Dec.2004.

[25] Smitha, S., Pandeya, S.N., Stables, J.P. and Ganapathy, S. "Anticonvulsant and sedative-hypnotic activities of NAcetyl/Methyl isatin derivatives".Sci Pharm, 76.621-636. Sept. 2008. 